\title{
Faunistic patterns and diversity components of leech assemblages in karst springs of Montenegro
}

\author{
Nikola Marinković ${ }^{1, *}$, Branko Karadžić ${ }^{1}$, Vladimir Pešić ${ }^{2}$, Bogić Gligorović ${ }^{2}$, Clemens Grosser ${ }^{3}$, \\ Momir Paunović ${ }^{1}$, Vera Nikolić ${ }^{4}$ and Maja Raković ${ }^{1}$ \\ ${ }^{1}$ Institute for Biological Research "Siniša Stanković", University of Belgrade, Bulevar despota Stefana 142, 11060 Belgrade, Serbia \\ ${ }^{2}$ Department of Biology, Faculty of Sciences, University of Montenegro, Cetinjski put b.b., 81000 Podgorica, Montenegro \\ ${ }^{3}$ Bernd-Blindow-Schule Leipzig, Comeniusstraße 17, 04315 Leipzig, Germany \\ ${ }^{4}$ University of Belgrade, Faculty of Biology, Studentski trg 16, 11000 Belgrade, Serbia
}

Received: 21 January 2019 / Accepted: 28 April 2019

\begin{abstract}
The aim of this study was to reveal faunistic and diversity patterns and to assess the effects of environmental factors on the differentiation of leech communities. This study covers investigations of 82 karst springs in Montenegro from 2009-2017. The communities were analyzed in respect to five wellspring types - caves, sublacustrine, limnocrene, rheo-limnocrene and rheocrene. The percentage of substrate types and aquatic vegetation cover was recorded alongside water parameters. In total, 18 leech species were identified, of which two were recently described as new species for science (Dina minuoculata Grosser, Moritz and Pešić, 2007 and Glossiphonia balcanica Grosser and Pešić, 2016). K-means clustering was used to classify leech assemblages into three homogenous groups. The patterns of leech communities and the components of both alpha and beta diversity were examined in identified groups of assemblages. The significance of environmental factors and the impact of selected factors were assessed through forward selection analysis, CCA and RDA. Our results indicate that the type of spring and the environmental variables, as well as the combination of biotic and abiotic factors in a microhabitat dictate the distribution of leeches.
\end{abstract}

Keywords: hirudinea / crenobiology / alpha and beta diversity / cca/rda

Résumé - Structures faunistiques et composantes de la diversité des assemblages de sangsues dans les sources karstiques du Monténégro. L'objectif de cette étude était de révéler les schémas faunistiques et de diversité et d'évaluer les effets des facteurs environnementaux sur la différenciation des communautés de sangsues. Cette étude porte sur 82 sources karstiques au Monténégro de 2009-2017. Les communautés ont été analysées en fonction de cinq types de sources d'eau-grottes, sous-lacustres, limnocrènes, rhéo-limnocrènes et rhéocroènes. Le pourcentage de types de substrat et de couverture végétale aquatique a été enregistré en même temps que les paramètres de l'eau. Au total, 18 espèces de sangsues ont été identifiées, dont deux ont été récemment décrites comme de nouvelles espèces pour la science (Dina minuoculata Grosser, Moritz et Pešić, 2007 et Glossiphonia balcanica Grosser et Pešić, 2016). Le regroupement $K$-means a été utilisé pour classer les assemblages de sangsue en trois groupes homogènes. Les modèles des communautés de sangsues et les composantes de la diversité alpha et bêta ont été examinés dans des groupes d'assemblages identifiés. L'importance des facteurs environnementaux et l'impact de certains facteurs ont été évalués au moyen d'une analyse de sélection prospective, de CCA et de RDA. Nos résultats indiquent que le type de source et les variables environnementales, ainsi que la combinaison de facteurs biotiques et abiotiques dans un microhabitat dictent la distribution des sangsues.

Mots-clés : hirudinée / crénobiologie / diversité alpha et bêta / cca/rda

\footnotetext{
*Corresponding author: nikola.marinkovic@ibiss.bg.ac.rs
} 


\section{Introduction}

Due to complex trophic relationships, leeches are important components of wetland and aquatic ecosystems (Elliott and Mann, 1979; Borda and Siddall, 2004; Lunghi et al., 2018). They are top predators and ectoparasites that control prey and host populations in spring ecosystems. At the same time, leeches are prey for many carnivorous species (Koperski, 2006; Kubová et al., 2013; Cichocka et al., 2015; Živić et al., 2015).

Leeches are generally considered as useful indicators in the biological assessment and monitoring of water quality (Friese et al., 2004; Koperski, 2006, 2017). However, their populations are endangered by industrialization and excessive exploitation of natural resources (Stendera et al., 2012).

Physical and chemical variables of water, substrate type and food availability are the main factors determining the distribution patterns of free-living leeches (Koperski, 2006, 2010; Beracko and Košel, 2011; Kubová et al., 2013; Cichocka et al., 2015).

Despite long term studying of leeches in Montenegro and adjacent areas (Blanchard, 1905; Augener, 1937; Rémy, 1937; Sket, 1968; Šapkarev, 1975; Utevsky et al., 2013; Grosser and Pešić, 2005; Grosser et al., 2007, 2014a; Živić et al., 2017), the available information on species distribution and the ecology of leech assemblages is incomplete.

In general, species diversity involves alpha (withincommunity) diversity, beta (between-communities) diversity and gamma diversity or overall biodiversity within a region of concern (Whittaker, 1972). Alpha diversity depends on the number of species present in a community (species richness) and the evenness of the individuals that are distributed among these species (species equitability) or species evenness (Lloyd and Ghelardi, 1964; Pielou, 1969, 1974).

Beta diversity (between-community dissimilarity) can be partitioned into two additive components: the dissimilarity due to the difference in species richness (nestedness) and the dissimilarity associated with the replacement of some species by others between assemblages (Baselga, 2010; Podani et al., 2013; Legendre, 2014).

We surveyed karst springs in Montenegro in order to (1) detect faunistic patterns of leech assemblages, (2) detect the patterns of diversity components in analyzed leech assemblages, and (3) to examine the effects of environmental factors (water parameters, substrate composition, aquatic vegetation and modification of springs) on the differentiation of leech communities.

\section{Material and methods}

\subsection{Study area and sampling}

Extensive limnological investigations were conducted from 2009 to 2017 at a total of 82 wellspring sites (Appendix 1) in Montenegro. Samples were collected two times per site, once in the summer and once in the winter. Leeches were collected from five types of karst springs - cave, sublacustrine, limnocrene, rheo-limnocrene and rheocrene. Rheocrene springs emerge on the ground surface as one or more flowing streams while limnocrene have discharge that emerge from aquifers into one or more lentic pools (Springer and Stevens
2009). In addition to these two commonly used ecomorphological spring types (Di Sabatino et al., 2003), three additional ecomorphological types of springs were found in the studied area. Rheo-limnocrene with the characteristiscs of the above types, cave springs, and sublacustrine springs which are underwater depressions whose bottom extends deep below the lake floor (Barović et al., 2018). Some springs were modified for human use (diverted into pipes) or turned into livestock troughs. The study area included springs from a wide territory, from the southern part of Montenegro (the drainage basin of Lake Skadar), to the northern part of the country (the Tara River) (Fig. 1). The Lake Skadar is the largest lake on the Balkan Peninsula and is located in the area of Dinaric karst, with a surface area that seasonally fluctuates between 370 and $600 \mathrm{~km}^{2}$ (Pešić et al., 2018) The lake is well-known for the occurrence of numerous karstic springs (Radulović et al., 2015). Most of them are rheocrene and limnocrene springs. There are also numerous sublacustrine springs that occur along the coast of the Lake Skadar. Other karstic springs are located outside the drainage basin of the lake at higher altitudes.

Leeches were collected using a benthological hand net (mesh size $500 \mu \mathrm{m}$ ); additionally, individuals were collected by tweezers from hard substratum and vegetation. Each animal was relaxed in $10 \%$ ethanol and then transferred to $70 \%$ ethanol for further analysis. In the laboratory, the stereomicroscopes Nikon SMZ8000N (magnification 10-80x) and Zeiss Stemi 2000-C (magnification 6.5-50x) were used for sorting and identification.

Leeches were identified up to the species level or to the lowest possible taxonomic level in the case of damaged or small-sized juvenile individuals according to Nesemann and Neubert (1999), Grosser et al. (2007, 2016). The qualitative composition of the leeches was determined for each site (Appendix 2), along with species occurrence frequencies $(\mathrm{F}=0-1)$ per spring type. The ASTERICS software package Version 3.1.1. (AQEM, 2002) was used for assessment of data and calculation of metrics.

\subsection{Environmental variables}

The GPS position and altitude of each site was recorded using a Garmin eTrex 20x Handheld GPS Receiver.

Water temperature and $\mathrm{pH}$ were measured in the field with a pH meter (HI 98127, accuracy 0.1).

In each spring we categorized the substrate types and aquatic vegetation coverage according to von Fumetti et al. (2006). The substrate types included rocks (ROC), stones (STO), gravel (GRA), sand (SAN), clay (CLA) and anoxic mud (ANM), going from largest to finest fractions. Aquatic vegetation included algae (ALG), mosses (MOS) and macrophytes (MCP). Both substrate types and aquatic vegetation coverage were categorized into four classes of frequency based on the percentage of cover: $0(0 \%) ; 1(1-25 \%) ; 2(26-50 \%) ; 3$ $(51-75 \%)$ and $4(76-100 \%)$. Human impact (N/M variable) was assessed by assigning 1 to natural and 2 to modified springs (Appendix 3).

\subsection{Data processing}

$K$-means clustering (MacQueen, 1967; Hastie et al., 2009) was used to obtain maximally homogeneous groups of 


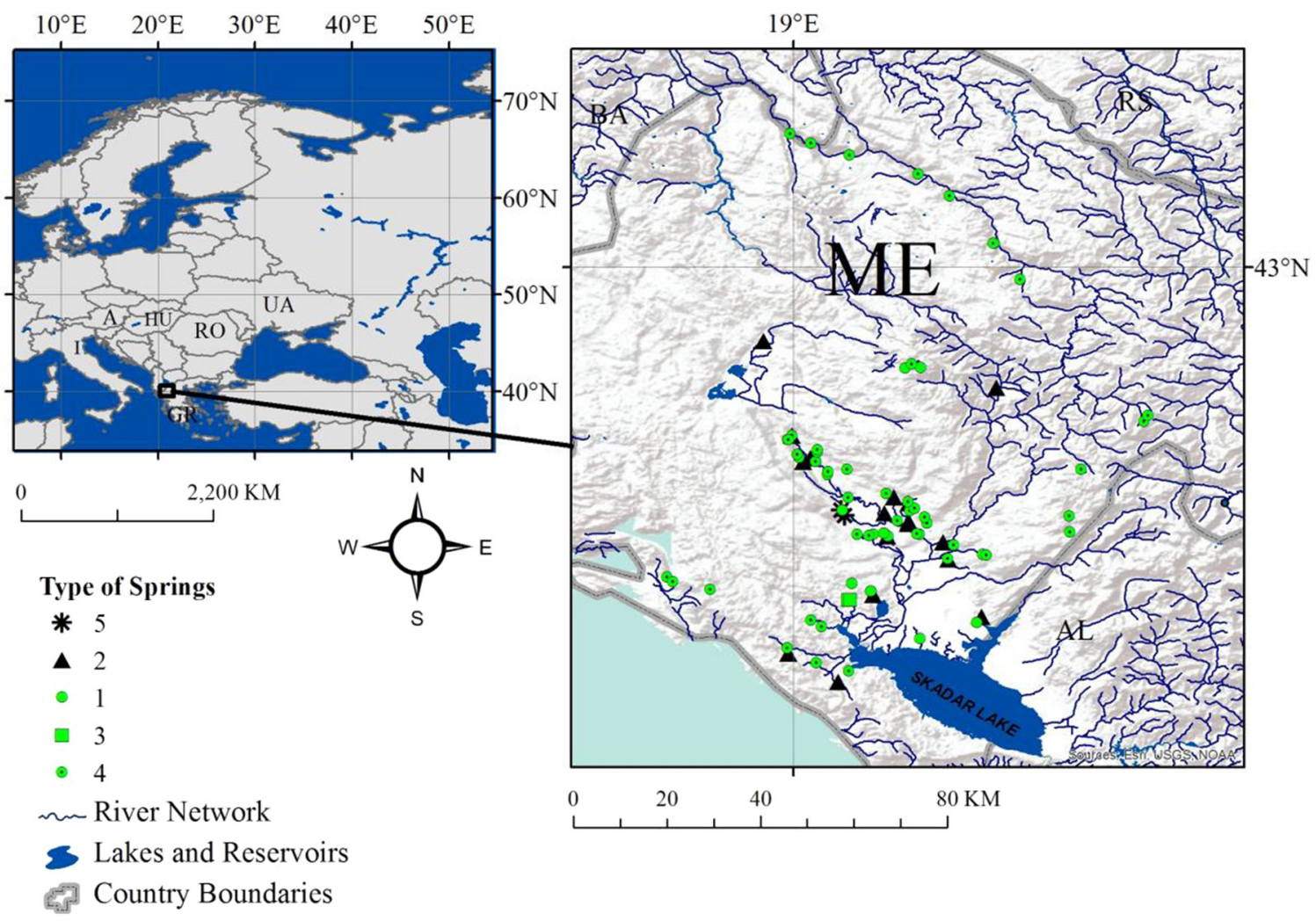

Fig. 1. Map of sampling sites for leeches in karst springs of Montenegro during 2009-2017 (1-limnocrene; 2-rheo-limnocrene; 3 -sublacustrine; 4 -rheocrene; 5 -cave springs).

communities. The method classifies a data set into a prespecified number of clusters. The main drawback of the method is subjectivity in the initial guess of the number of clusters. To avoid this problem, we selected the number of clusters by maximizing the variance ratio:

$$
V R=\frac{\sigma_{b}^{2}}{\sigma_{w}^{2}}
$$

where $\sigma_{b}^{2}$ denotes the between-group variance (i.e. variance of cluster centroids), and $\sigma_{w}^{2}$ is the within-group variance (the sum of variances within each of $k$ clusters). Maximization of the variance ratio assures that overlap of homogeneous clusters is minimized.

We used linear discriminant analysis - LDA (Fisher, 1936; Greenacre, 2010) to find a combination of species that maximally discriminates extracted clusters of communities.

Within each type of leech assemblage, we investigated components of alpha and beta diversity.

Alpha diversity was assessed using Shannon's entropy:

$$
H=-\sum_{i=1}^{s} p_{i} \log p_{i}
$$

where $p_{i}$ is the proportion of species $i$ within a site, and $s$ denotes the number of species within the site. Shannon's entropy varies from $H_{\min }=0$ (in the case of one-species community) to $H_{\max }=\log (s)$.
The equitability component of alpha diversity may be calculated using the equation:

$$
E=H / H_{\max }=-\sum_{i=1}^{s} p_{i} \log p_{i} / \log s,
$$

where $H_{\max }$ is the greatest possible entropy. Equitability is an indeterminate ratio $0 / 0$ if a sample has only one species. To avoid such indeterminate cases, we calculated equitability using the modified equation:

$$
E=-\sum_{i=1}^{s} p_{i} \log p_{i} / \log (s+0.01) .
$$

After this modification, the equitability varied from 0 , to a number that approximated 1 .

In this study, we detected components of beta diversity using the procedures described by Baselga (2010) and Podani et al. (2013).

Forward selection (FS) was used to detect predictors (environmental variables) with statistically significant effects on the variability of the analyzed leech communities. The variable selection methods can operate using either parametric or non-parametric statistical tests (Miller, 1984). Compared to parametric tests, the non-parametric alternatives have an essential advantage (Anderson, 2001, 2005). Therefore, we tested the hypothesis on species-environment independence 
Table 1. Selection of an optimal number of clusters based on the ratio of between-group to within-group variances.

\begin{tabular}{llll}
\hline $\mathrm{Nc}$ & $\mathrm{BgV}$ & $\mathrm{WgV}$ & $\mathrm{VR}$ \\
\hline 2 & 0.2507 & 0.7834 & 0.3199 \\
3 & 0.3491 & 1.0625 & 0.3286 \\
4 & 0.3811 & 1.2854 & 0.2965 \\
5 & 0.3947 & 1.5954 & 0.2474 \\
6 & 0.4403 & 1.6718 & 0.2634 \\
7 & 0.4824 & 1.7994 & 0.2681 \\
8 & 0.5306 & 2.1432 & 0.2476 \\
9 & 0.4983 & 2.1653 & 0.2301 \\
10 & 0.5959 & 2.1378 & 0.2788 \\
\hline
\end{tabular}

Abbreviations: $\mathrm{N}$-number of clusters; $\mathrm{BgV}$-between-group variance; $\mathrm{WgV}$ - withingroup variance; $\mathrm{VR}$ - variance ratio (betweengroup to within-group variance).

using a non-parametric Monte Carlo permutation test (3000 permutations, $p<0.05$ ).

Using statistically significant environmental variables, we performed both canonical correspondence analysis-CCA (Ter Braak, 1986) and distance-based redundancy analysis RDA (Legendre and Anderson, 1999) to detect the simultaneous effect of selected variables on faunistic differentiation of leech communities.

Statistical analyses were performed using FLORA software (Karadžić, 2013), updated version.

\section{Results}

Over the seven-year study, in 164 samples taken from 82 karst springs of Montenegro, the subclass Hirudinea was represented by 844 individuals with 18 species. Representatives of Rhynchobdellida and Arhynchobdellida were recorded. Species belonged to 4 families and 9 genera.

Ordo Rhynchobdellida was represented with nine species belonging to the family Glossiphoniidae, mostly in sublacustrine and limnocrene springs. The species Placobdella costata (Fr. Müller, 1846) was found in all types of springs and was the most frequent. Hemiclepsis marginata (O.F. Müller, 1774) predominantly inhabited limnocrene springs, while Glossiphonia balcanica Grosser and Pešić, 2016, Glossiphonia paludosa (Carena, 1824), Alboglossiphonia heteroclita (L., 1761) and Alboglossiphonia striata (Apáthy, 1888) were found only in sublacustrine springs. Glossiphonia concolor (Apáthy, 1888) was only recorded in one cave and in one limnocrene spring.

Ordo Arhynchobdellida included species classified in the subordo Hirudiniformes and subordo Erpobdelliformes.

The subordo Hirudiniformes was represented by two species, Haemopis sanguisuga (L., 1758) and Hirudo verbana Carena, 1820.

$H$. sanguisuga was the most frequent leech species in limnocrene springs $(\mathrm{F}=0.69)$, followed by $P$. costata $(\mathrm{F}=0.54)$. The species $H$. verbana preferred caves, limnocrene and rheo-limnocrene springs.

Seven taxa belonging to the subordo Erpobdelliformes were recorded during this study. During our research, the erpobdellid leech, Dina dinarica Sket, 1968, was observed to be the most common species, occurring in more than $60 \%$ of springs in the southern part of Montenegro. It inhabited all five spring types and was the most common species in rheolimnocrene $(\mathrm{F}=0.7)$ and in rheocrene $(\mathrm{F}=0.67)$ springs. Erpobdella octoculata (L., 1758) was found in all sublacustrine springs and in one limnocrene and one rheo-limnocrene spring. Other species of Erpobdelliformes are rare species and were only found at a few sites.

The glossiphoniid leech $P$. costata was the most common species in limnocrene springs, while in sublacustrine springs several species of the Glossiphoniidae family (G. paludosa, $G$. balcanica, A. heteroclita and $A$. striata) were recorded.

Five species that were recorded are considered endemic for the Balkan Peninsula, including two species recently described as new for science, G. balcanica and D. minuoculata. Other recorded species have large distribution ranges.

The majority of recorded taxa are predators $(83.33 \%)$, while $16.67 \%$ are parasites (H. verbana. H. marginata and P. costata) (based on the autecological characterization of taxa provided by Moog, 2002). The recorded leeches prefer a hard substratum such as gravel, stone, and aquatic macrophytes, whereas the majority of taxa (42\%) use walking/sprawling as a means of locomotion, and less than $10 \%$ are swimmers or (semi)sessile (for $48 \%$ of taxa the data on locomotion is lacking (Moog, 2002).

\subsection{Classification of leech assemblages}

We classified leech communities using two approaches. The first approach was based on the faunistic similarity of the analyzed communities. Alternatively, the communities were classified a priori, according to the types of springs in which they occurred.

Ratio of between-group to within-group variances for different number of clusters obtained through $K$-means clustering is shown in Table 1. The maximal variance ratio indicated three clusters form the most homogeneous groups of communities.

LDA provided a combination of species that maximally discriminated between three clusters of communities (Fig. 2a). The species $H$. sanguisuga dominated in the first group of communities, and was frequently associated with $H$. verbana and Erpobdella vilnensis (Liskiewicz, 1925). This group included species that occur rarely, such as Trocheta dalmatina Sket, 1968; Dina montana Sket, 1968; D. minuoculata and Erpobdella nigricollis (Brandes, 1900).

The dominant species in the second group of communities was $P$. costata. It was associated with Glossiphonia complanata (L., 1758), Glossiphonia nebulosa Kalbe, 1964, G. paludosa, G. balcanica, H. marginata, A. heteroclita, A. striata and E. octoculata.

The species $D$. dinarica was almost exclusive to the third type of community. $H$. marginata, $G$. complanata and E. octoculata occurred sporadically. P. costata, D. dinarica, $H$. sanguisuga and $H$. verbana were found in all types of assemblages (Tab. 2).

Beside faunistic classification, we categorized communities according to the type of springs where they occurred. The extracted groups exhibited a low variance ratio $(\mathrm{VR}=$ 0.0192 ). LDA provided similar results, centroid of all groups overlap, with exception of two sublacustrine springs (Fig. 2b). 

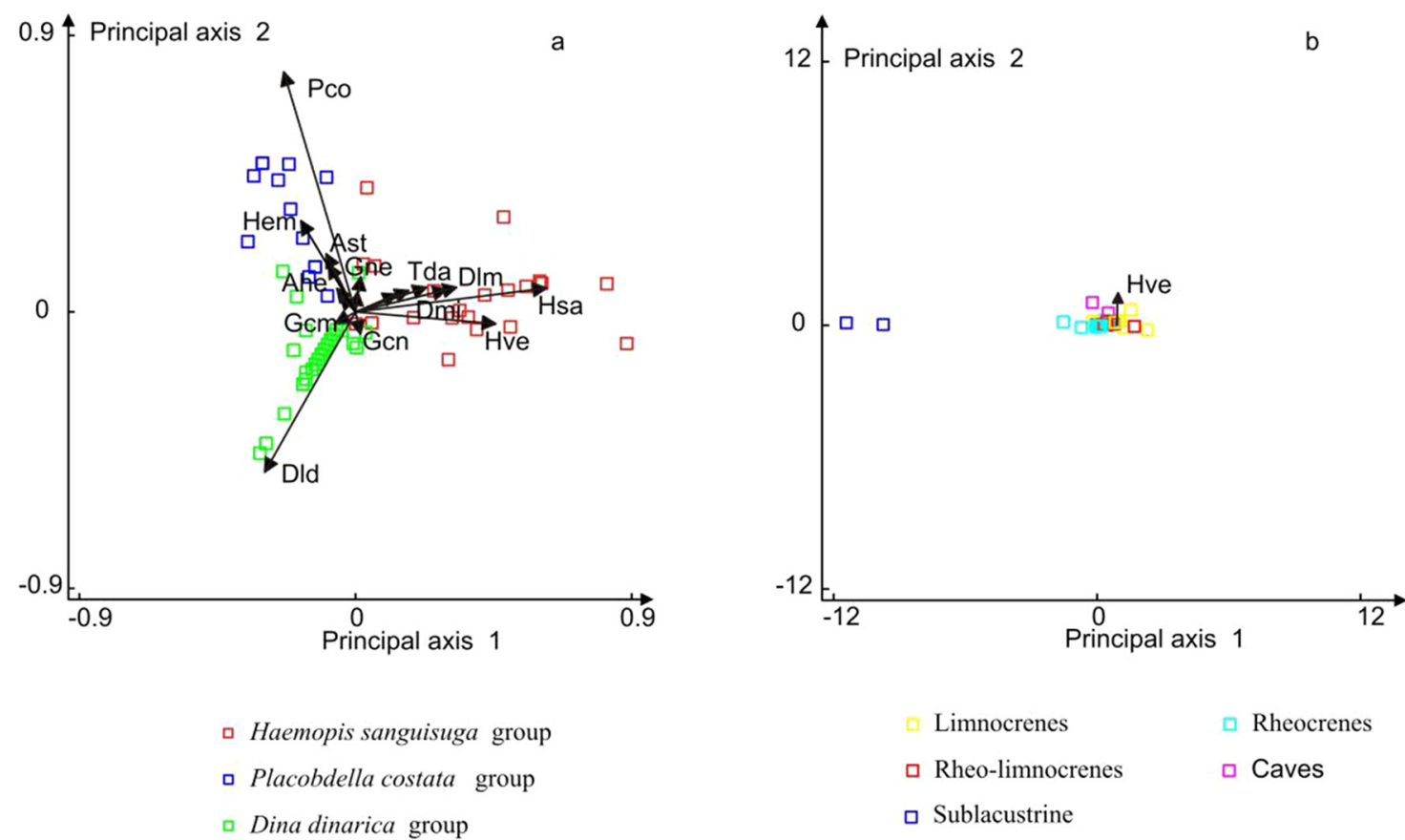

Fig. 2. a: LDA based on the groups of faunistically similar leech assemblages, dominated by the Haemopis sanguisuga (1), Placobdella costata (2) and Dina dinarica (3) groups. (for codes of species presented on the plots refer to Appendix 2); b: LDA based on groups of communities that occur in different types of springs ( $\mathrm{L}$ - limnocrene; R-L - rheo-limnocrene; SL-sublacustrine; $\mathrm{R}$-rheocrene; $\mathrm{C}$-caves, for codes of species presented on the plots refer to Appendix 2).

Table 2. Frequency of species occurring in three groups of assemblages.

\begin{tabular}{|c|c|c|c|}
\hline \multirow[t]{2}{*}{ Species } & $\begin{array}{l}\text { Haemopis } \\
\text { sanguisuga } \\
\text { group }\end{array}$ & $\begin{array}{l}\text { Placobdella } \\
\text { costata } \\
\text { group }\end{array}$ & $\begin{array}{l}\text { Dina } \\
\text { dinarica } \\
\text { group }\end{array}$ \\
\hline & $\mathrm{F}$ & $\mathrm{F}$ & $\mathrm{F}$ \\
\hline Haemopis sanguisuga (Hsa) & 0.78 & 0.21 & 0.11 \\
\hline Hirudo verbana (Hve) & 0.35 & 0.07 & 0.02 \\
\hline Placobdella costata (Pco) & 0.22 & 0.93 & 0.11 \\
\hline Dina dinarica $(\mathrm{Dld})$ & 0.09 & 0.29 & 1.00 \\
\hline Erpobdella vilnensis (Evi) & 0.13 & 0.00 & 0.00 \\
\hline Erpobdella octoculata (Eoc) & 0.00 & 0.21 & 0.02 \\
\hline Erpobdella nigricollis (Eni) & 0.09 & 0.00 & 0.00 \\
\hline Dina minuoculata (Dmi) & 0.04 & 0.07 & 0.00 \\
\hline Dina montana (Dlm) & 0.09 & 0.00 & 0.00 \\
\hline Trocheta dalmatina (Tda) & 0.09 & 0.00 & 0.00 \\
\hline $\begin{array}{l}\text { Glossiphonia } \\
\text { complanata }(\mathrm{Gcm})\end{array}$ & 0.04 & 0.07 & 0.05 \\
\hline $\begin{array}{l}\text { Alboglossiphonia } \\
\text { heteroclita (Ahe) }\end{array}$ & 0.00 & 0.14 & 0.00 \\
\hline Glossiphonia nebulosa (Gne) & 0.00 & 0.14 & 0.00 \\
\hline Glossiphonia paludosa (Gpa) & 0.00 & 0.14 & 0.00 \\
\hline Alboglossiphonia striata (Ast) & 0.00 & 0.14 & 0.00 \\
\hline Glossiphonia concolor (Gen) & 0.09 & 0.00 & 0.00 \\
\hline Glossiphonia balcanica (Gba) & 0.00 & 0.14 & 0.00 \\
\hline Hemiclepsis marginata (Hem) & 0.04 & 0.14 & 0.02 \\
\hline
\end{tabular}

Abbreviations: $\mathrm{F}$-frequency of occurring in group of assemblages.
Between-group variance was low (0.0506) while within-group variance was high (2.634).

Correspondence between faunistic groups and spring types is presented in a histogram (Fig. 3). Leech assemblages with $P$. costata inhabit four types of springs, mostly limnocrene, rheo-limnocrene and sublacustrine. Communities dominated by $D$. dinarica usually occur in rheocrene and rheo-limnocrene springs. Leech communities with $H$. sanguisuga usually occur in limnocrene and rheocrene springs, but not in sublacustrine springs.

\subsection{Distributional patterns of leech assemblages}

Springs inhabited by different groups of leech assemblages significantly differ with respect to altitude (Fig. 4). The assemblages that belong to the $P$. costata group occur at the lowermost altitudes (mainly in springs around Lake Skadar). Most of the assemblages that belong to the $H$. sanguisuga group predominate in mountainous springs. However, these communities also occur in lowland and altimontane regions. Due to the wide altitudinal range of springs inhabited by the $H$. sanguisuga group of leech assemblages, their species composition was the most heterogeneous.

\subsection{Diversity components}

We analyzed the components of alpha (within-community) diversity within each of faunistically homogeneous groups of communities. Three types of leech assemblages differ significantly with respect to the components of alpha diversity 


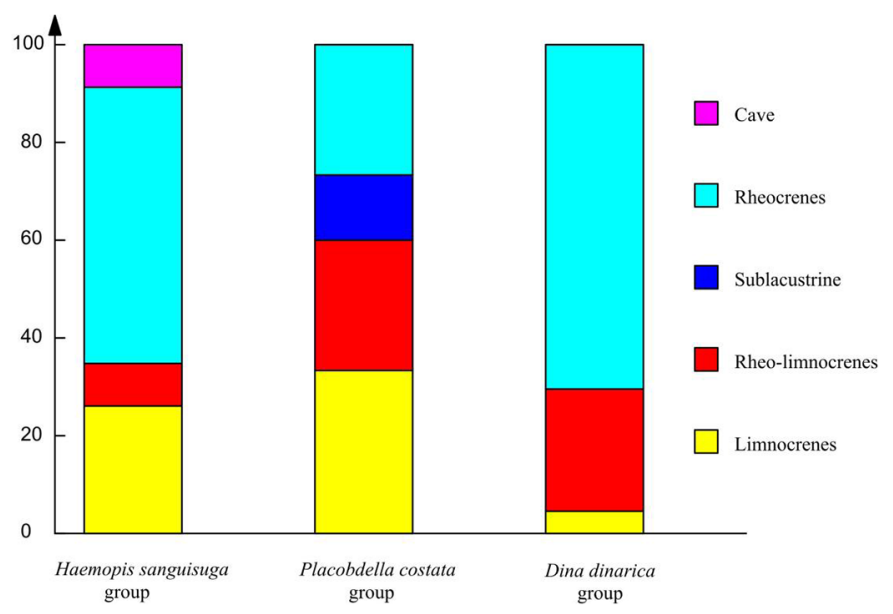

Fig. 3. Correspondence between faunistic groups of leech assemblages and types of springs.

(Fig. 5). Species-poor leech assemblages, dominated by D. dinarica, were usually represented by one, and in some cases only three species. Compared to leech assemblages dominated by $D$. dinarica, assemblages with $P$. costata and $H$. sanguisuga had significantly higher numbers of species (Shannon's entropy and equitability).

The greatest number of species was recorded in leech communities dominated by $P$. costata. These communities occurred in springs with the most diverse microhabitats (sublacustrine, limnocrene and rheo-limnocrene springs) that offered many ecological niches supporting high species richness. However, this group of communities also occurred in rheocrene springs with only one or a few species. Shannon's entropy and species richness had similar trends. Equitability of species abundances decreased from leech communities dominated by $H$. sanguisuga to communities with $D$. dinarica. The relatively low equitability in communities with $P$. costata can be explained by the effects of species-poor rheocrene springs.

We assessed total beta diversity, and its components using two alternative approaches (Baselga, 2010; Podani et al., 2013); however, both approaches provided essentially the same result.

Beta diversity increased from leech assemblages with $D$. dinarica to assemblages dominated by $H$. sanguisuga.

To detect percentage contributions of nestedness and species turnover to the beta diversity, we used a ternary plot (Fig. 6).

The lowest values of both nestedness and species turnover were detected in leech assemblages with a domination of D. dinarica. Nestedness (differences in species richness) was more important than species replacement in assemblages dominated by $P$. costata. This indicated that the relative contribution of species loss to the beta diversity was more important than species replacement. Quite an opposite trend was observed for leech assemblages dominated by H. sanguisuga.

\subsection{Effects of environmental variables on the variability of leech assemblages}

After performing FS, we observed that all geographic variables (latitude, longitude and altitude) had a significant effect on the differentiation of analyzed communities (Tab. 3). Water parameters, acidity $(\mathrm{pH})$ and temperature recorded in winter $\left(\mathrm{T}^{\circ} \mathrm{C} \_\mathrm{w}\right)$ and in summer $\left(\mathrm{T}^{\circ} \mathrm{C} \_\mathrm{s}\right)$, had statistically insignificant effects on the leech assemblage due to low fluctuations during the sampling season. The lowest temperature recorded in winter was $6.9^{\circ} \mathrm{C}$ and the highest was $13.4^{\circ} \mathrm{C}$, while the average value was $10.4^{\circ} \mathrm{C}$. The acidity ranged from pH 6.92 to 7.59, with an average pH of 7.3. Only two out of six substrate characteristics (percentage of sand and rock particles) were significant. Considering the vegetation characteristics, the most influential predictor was the percentage of moss cover. Other variables were statistically insignificant. The habitat variables (type of springs and anthropogenic modification of habitats) had statistically significant effects on the leech assemblage patterns.

The synergic effect of all (statistically significant) variables on the faunistic variability of leech communities was analyzed using canonical correspondence analysis (CCA).

The first two CCA axes explained $52.4 \%$ of the variation of the fitted data, obtained by multiple regressions. Environmental predictors explained a relatively small portion of the total variability of leech distributions $\left(\mathrm{R}^{2}=0.307\right)$. CCA indicated that the spatial variables (altitude and longitude - eastward) had the most prominent effects on data variability (Fig. 7a). In two subalpine springs (altitude $1800 \mathrm{~m}$ ), only one species (D. montana) was recorded. Most springs with E. vilnensis and $H$. sanguisuga were also located at high altitudes. CCA emphasized these species and communities where they occurred.

The importance of other environmental variables was much lower. As CCA results indicated, the type of spring had a small effect on the faunistic differentiation of the analyzed leech communities.

The application of distance-based RDA to our data set confirmed that environmental predictors explained a relatively small part of the total variability of leech distributions $\left(\mathrm{R}^{2}=0.279\right)$. The first two d-b RDA axes explained $86 \%$ of the variation of the fitted data.

As with CCA, the d-b RDA also emphasized the importance of $H$. sanguisuga, E. vilnensis, D. montana and subalpine springs where they occurred. The vector of the altitude variable is orientated along the second principal axis, contrary to CCA. The d-b RDA produced more interpretable results with respect to the effects of other factors (types of habitats, variables specifying bottom structure, vegetation, modification of springs) on faunistic variability. Communities dominated by $D$. dinarica were separated from other communities (Fig. 7b).

\section{Discussion}

The leech fauna of Montenegro includes 29 taxa, 26 species and $D$. lineata represented by three subspecies (Grosser et al., 2014a). The taxa list also includes two species recently described as new for science (Grosser et al., 2007, 2016). Our study of karstic springs revealed the presence of 18 species $(62 \%$ of the total number of recorded taxa in Montenegro). Leech fauna of the Balkans, particularly the family Erpobdellidae, still remains relatively unknown. According to Sket (1968), in the Dinaric karst areas of the western Balkan Peninsula, as well as in the southeastern preAlpine region, four distinct erpobdellid leech taxa are known. 

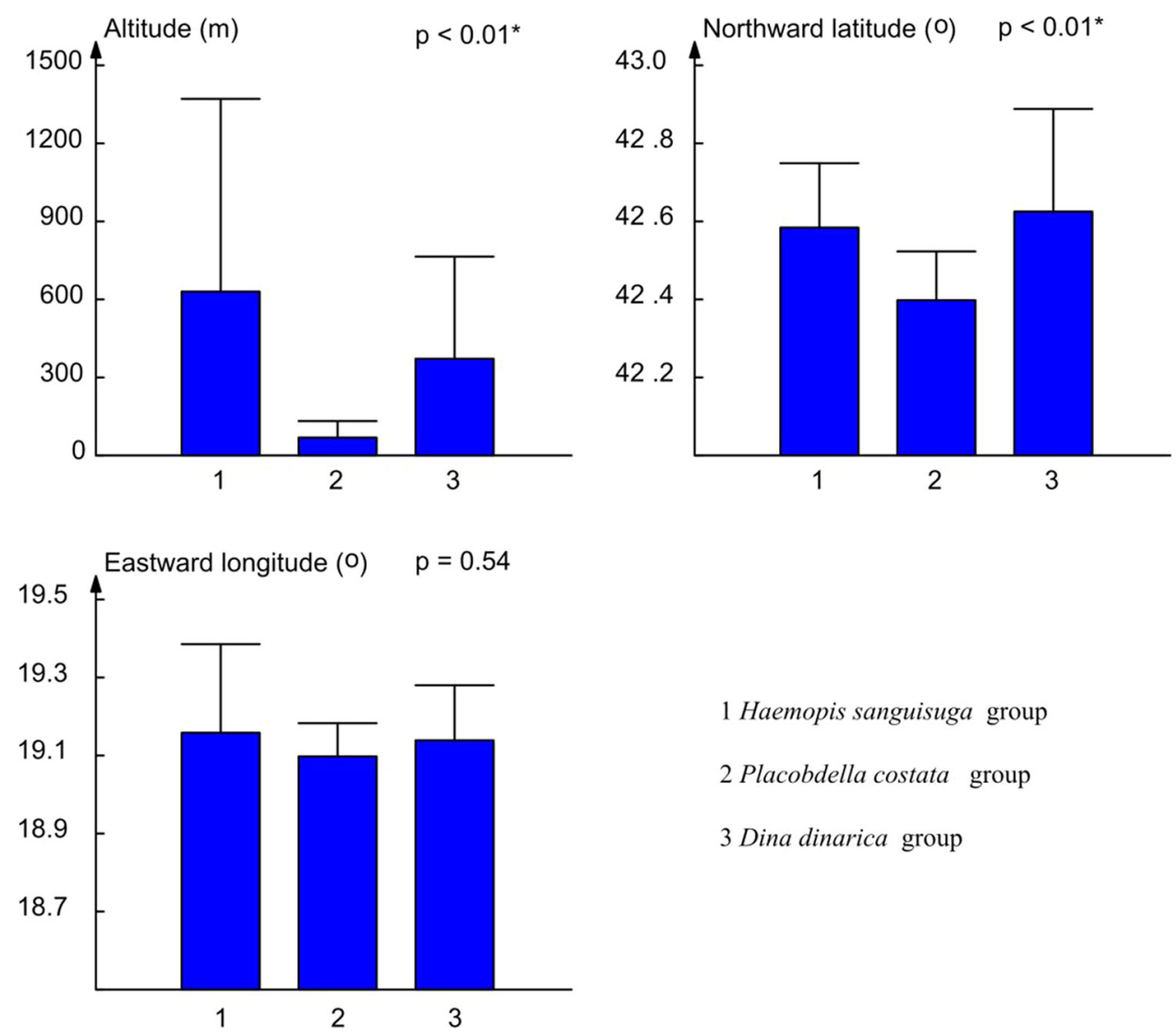

\author{
1 Haemopis sanguisuga group \\ 2 Placobdella costata group \\ 3 Dina dinarica group
}

Fig. 4. Altitude and geographic positions of springs inhabited by three groups of leech assemblages. For each group of assemblages, the mean values and variances of altitude, Northward latitude and Eastward longitude of springs are represented by bars and lines, respectively.

The northwestern parts of this range are occupied by Trocheta cylindrica Örley, 1886, in the southern part they are replaced by Dina lineata dinarica Sket, 1968 (Dalmatia (Croatia), Hercegovina and Montenegro), the southernmost area of this range is occupied by $D$. lineata montana Sket, 1968 (the alpine region of Montenegro), and the fourth taxon, Dina krasensis (Sket, 1968), occurs in a relatively narrow area between the first two taxa, which inhabit southern Slovenia and northwestern Croatia (Grosser et al., 2014b).

The taxonomical status of two former subspecies of D. lineata (D. l. dinarica and D. l. montana) recorded in this study and their relation with the subspecies D. l. lineata (O.F. Muller, 1774) is unclear. They should be treated as separate species or as subspecies of Dina dinarica Sket, 1968 (Grosser et al., 2016).

T. dalmatina is an endemic erpobdellid species that inhabits small streams in the narrow zone of the Adriatic coast from Croatia, Dubrovnik to Montenegro, Lake Skadar (Nesemann and Neubert, 1999; Grosser et al., 2014a).

The two approaches used to classify leech communities in karst springs gave different results. The first approach, based on the faunistic similarity of the analyzed communities, resulted in three distinct groups that had low within-group variability, while between-group variability was high. Classification of communities based on the type of spring gave opposite results.

The low variance ratio of extracted groups $(\mathrm{VR}=0.0192)$ clearly indicated that the classification based on the type of springs is suboptimal when compared to classification based on faunistic similarity. Linear discriminant analysis confirmed this conclusion, since the centroids of all groups, with the exception of sublacustrine springs, overlap. Due to the close proximity of centroids, between-group variance is low (0.0506). On the other hand, within-group variance is high (2.634).

The diversity of groups based on faunistic similarity differs greatly. In groups of assemblages dominated by $D$. dinarica all diversity components are very low. This type of leech assemblages occurred mainly in rheocrene springs with sandy and rock substrates. Distance based RDA highlighted that the type of spring and substrate are important factors in determining this group. Extremely low species turnover within these types of communities can be explained either by the unfavorable environmental conditions in rheocrene springs for other leech species, or by the competitive superiority of $D$. dinarica. Further investigations of competitive interactions of $D$. dinarica and other leech species are required.

The frequent occurrence of $D$. dinarica in rheocrene springs is expected because mountain and subalpine streams are typical habitats of this species (Sket, 1968). These findings are in agreement with the investigation of Kubová et al. (2013), where D. lineata was only found in lotic ecosystems.

During our research, the first of the two recently described species, D. minuoculata was recorded in epirhithral sectors in mountain streams of Montenegro, where it was also found for the first time (Grosser et al., 2007). 
N. Marinković et al.: Knowl. Manag. Aquat. Ecosyst. 2019, 420, 26
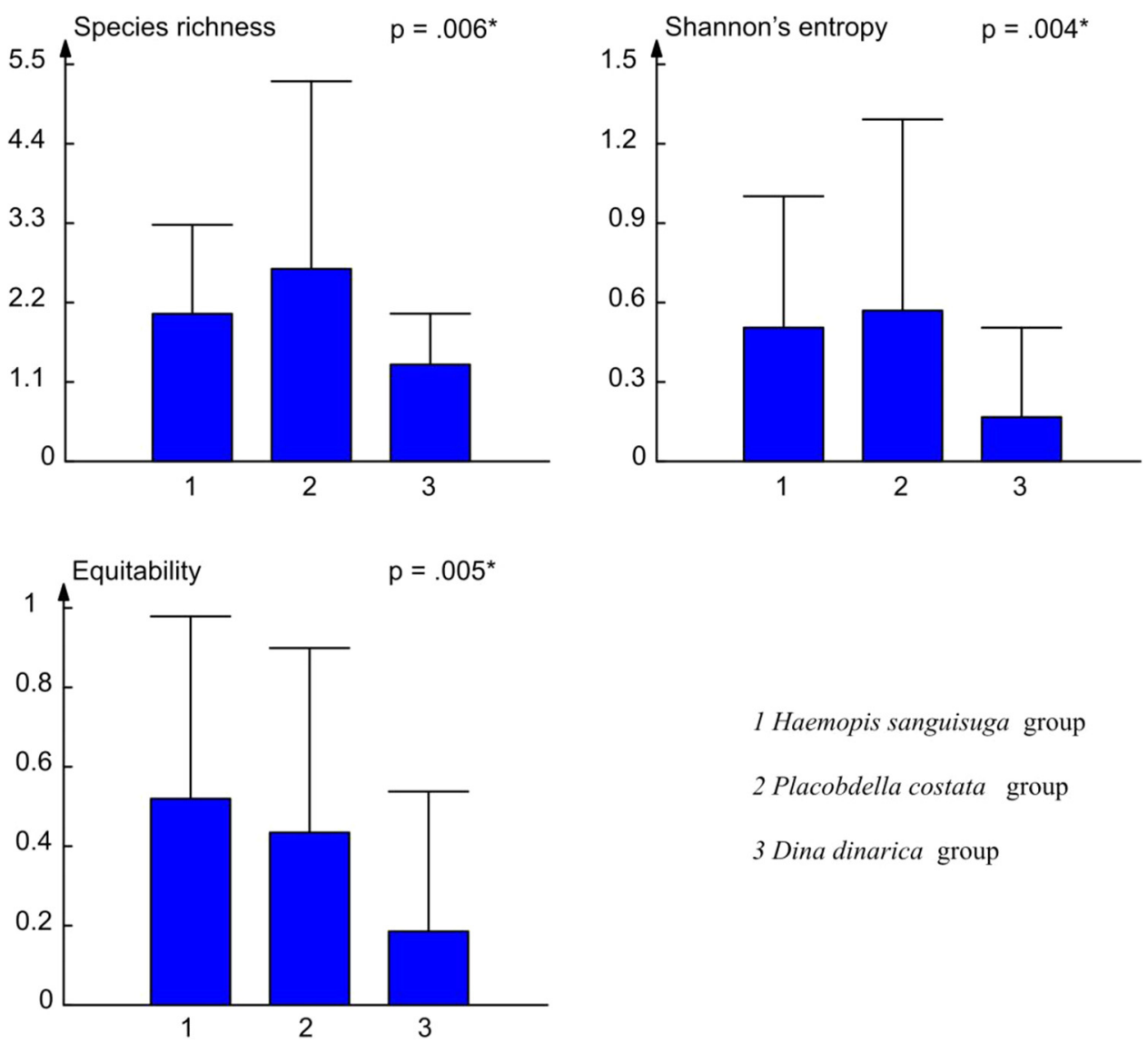

$$
\begin{aligned}
& 1 \text { Haemopis sanguisuga group } \\
& 2 \text { Placobdella costata group } \\
& 3 \text { Dina dinarica group }
\end{aligned}
$$

Fig. 5. Components of alpha diversity in leech assemblages dominated by Haemopis sanguisuga (1), Placobdella costata (2) and Dina dinarica (3).

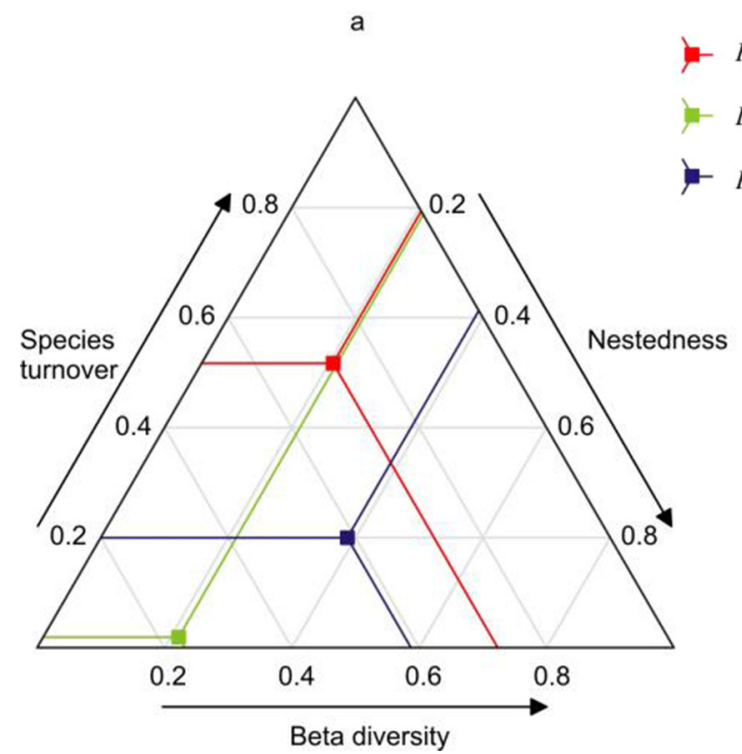

b

$$
\begin{aligned}
& \text { Haemopis sanguisuga group } \\
& \text { Dina dinarica group } \\
& \text { Placobdella costata group }
\end{aligned}
$$

Fig. 6. Components of beta diversity in three groups of leech communities. Components obtained according to: a: Baselga, 2010; b: Podani et al., 2013.

Other leech assemblage groups show greater species diversity. Both $H$. sanguisuga and $P$. costata groups have higher alpha and beta diversity components than the group represented by $D$. dinarica. The significant difference between leech assemblages dominated by $H$. sanguisuga and $P$. costata with respect to the species turnover component of beta 
Table 3. Results of forward selection analysis.

\begin{tabular}{|c|c|c|c|}
\hline Variables & & $\mathrm{F}$ ratio & Probability \\
\hline \multirow{3}{*}{ Geographic } & $\mathrm{E}$ & 8.072 & $0.001 *$ \\
\hline & Alt & 3.584 & $0.001 *$ \\
\hline & $\mathrm{N}$ & 2.483 & $0.016^{*}$ \\
\hline \multirow{3}{*}{ Water parameters } & $\mathrm{pH}$ & 1.894 & 0.335 \\
\hline & $\mathrm{T}^{\circ} \mathrm{C} \_\mathrm{W}$ & 2.375 & 0.126 \\
\hline & $\mathrm{T}^{\circ} \mathrm{C} \_\mathrm{s}$ & 1.734 & 0.254 \\
\hline \multirow{6}{*}{ Substrate } & SAN & 2.873 & $0.010^{*}$ \\
\hline & ROC & 2.733 & $0.040^{*}$ \\
\hline & GRA & 1.742 & 0.270 \\
\hline & CLA & 2.234 & 0.172 \\
\hline & STO & 1.302 & 0.166 \\
\hline & ANM & 1.352 & 0.110 \\
\hline \multirow{3}{*}{ Vegetation } & MOS & 3.122 & $0.028^{*}$ \\
\hline & ALG & 2.172 & 0.440 \\
\hline & MCP & 1.857 & 0.265 \\
\hline \multirow{2}{*}{ Habitat } & $\mathrm{N} / \mathrm{M}$ & 3.654 & $0.001 *$ \\
\hline & TOS & 2.757 & $0.004^{*}$ \\
\hline
\end{tabular}

Abbreviations: E-longitude (Eastward); Alt-altitude; N-latitude (Northward); $\mathrm{pH}$-acidity; $\mathrm{T}^{\circ} \mathrm{C} \_\mathrm{w}-$ winter temperature; $\mathrm{T}^{\circ} \mathrm{C} \_\mathrm{s}-$ summer temperature; SAN - sand; ROC - rocks; GRA - gravel; CLA - clay; STO - stones; ANM - anoxic mud; MOS - mosses; ALG - algae; MCP macrophytes; N/M - natural/modified springs; TOS - types of springs. Asterisk $(*)$ denotes parameters with statistically significant effects on the variability of the analyzed leech communities.

diversity can be explained by the heterogeneity of the habitats where these assemblages occur (Pianka, 1974). While leech assemblages with $H$. sanguisuga were recorded in springs located on a wide range of altitudes, from lowland to subalpine regions, leech assemblages dominated by $P$. costata were mainly recorded in sublacustrine, limnocrene and rheolimnocrene springs at lower altitudes of the Skadar Lake Basin.

The assemblages dominated by $H$. sanguisuga usually occur in limnocrene, rheo-limnocrene and rheocrene springs that form a diverse mosaic of microhabitats. Due to heterogenous microhabitats, the greatest alpha diversity was observed in leech assemblages dominated by $P$. costata. However, these communities occur in rheocrene springs also, where the number of species was low. Microhabitat complexity decreases from sublacustrine to rheocrene springs as follows: sublacustrine $\rightarrow$ limnocrene $\rightarrow$ rheo-limnocrene $\rightarrow$ rheocrene $\rightarrow$ cave springs. Significant reduction of microhabitat complexity is a selective pressure that reduces the number of species. Therefore, the high beta diversity in communities dominated by $P$. costata is attributable to the difference in species richness (nestedness) and not to species replacement. Quite the opposite trend was observed in communities dominated by $H$. sanguisuga. These communities occur in a wide altitudinal range. The high species turnover in this group of leech assemblages can be explained by the changes in environmental conditions along the altitudinal gradients. A long environmental gradient can result in the diversification of ecological niches (MacArthur, 1984) and increased species replacement along the gradient.

The $P$. costata group is mostly comprised of various Glossiphoniidae species. These species prefer stagnant water bodies (Nesemann and Neubert, 1999). They were usually found in limnocrene and sublacustrine springs in the Skadar Lake Basin in which lentic conditions prevail. P. costata is reported to build assemblages with numerous species of leeches usually in stagnant water bodies. Its abundance is associated with the presence of its food source; it feeds on the blood of pond turtles and amphibians (Spyra and Krodkiewska, 2013) so that the high frequency of this species could be the result of food availability in the investigated springs. High species nestedness in this group could be explained by a loss of favorable microhabitats in different types of springs. Sublacustrine and limnocrene springs could have more microhabitats with favorable conditions that Glossiphoniidae leeches prefer compared to rheo-limnocrene and rheocrene springs.

During our research, the second newly described species for science, $G$. balcanica, was found in two sublacustrine springs (Karuč and Volač) that occur along the coast of Lake Skadar. These two springs and the Mareza spring near Podgorica were the localities from which this species was described for the first time (Grosser et al., 2016).

CCA and d-b RDA confirmed that environmental predictors can explain the relatively small part of total variability of leech distributions. CCA indicates that spatial variables (altitude and eastward latitude) have the most influence on data variability. This finding can be explained by the specific topography of Montenegro (a strong altitudinal gradient in a southwest to northeast direction). In two subalpine springs (altitude above $1800 \mathrm{~m}$ ), only one species (D. montana) was recorded. Most springs with E. vilnensis and $H$. sanguisuga were also located at high altitudes. CCA emphasized these species and the communities where they occur. E. vilnensis is usually described as a low- to intermediate- altitude species (Nesemann and Neubert, 1999), while Agapow and Piekarska (2000) describe it as species characteristic for mountain streams in Poland. Our record at an altitude of $1786 \mathrm{~m}$ is considerably higher than the findings of Utevsky et al. (2012) from Ukraine (960 m) and Kazanci et al. (2015) from Turkey $(900 \mathrm{~m})$. The lower temperature of water could be the factor that separates this species from a similar species, E. octoculata (Kubová and Schenková, 2014).

Forward selection and distance-based redundancy analysis show that the presence/absence of modification influences leech communities. Concrete or wooden livestock troughs with hard flat bottoms are a good habitat for leeches. The accumulation of organic sediment and slowing of water could favor some prey items (oligochaeta and chironomidae larvae), thus providing good conditions for leeches (Adamiak-Brud et al., 2018). Modified springs were usually located in or close to urban areas and are vulnerable to inputs of pollutants, which reduce both water quality and habitat quality (Koperski, 2010).

The importance of other environmental variables is much lower. As CCA results indicate, the type of spring has a small effect on the faunistic differentiation of the analyzed leech 

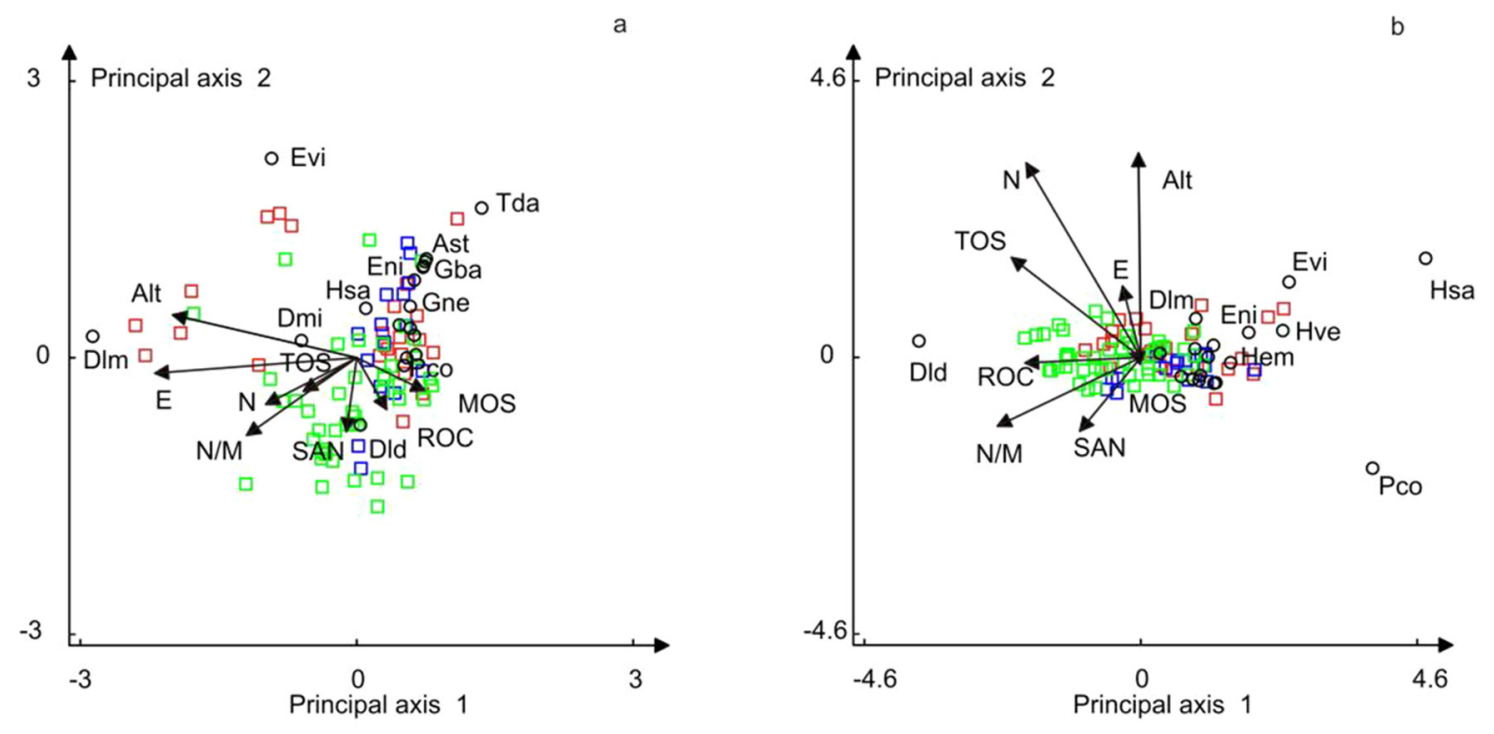

\footnotetext{
Haemopis sanguisuga group

ㅁ Placobdella costata group

$\square$ Dina dinarica group
}

Fig. 7. a: results of canonical correspondence analysis of impact of selected factors on leech assemblages; b: results of distance-based RDA analysis of impact of selected factors on leech assemblages (Alt - altitude; N-latitude (Northward); E-longitude (Eastward); N/M-human impact: natural or artificially modified springs; TOS-type of spring; ROC-rock; SAN-sand; MOS - moss).

communities. This finding is in accordance with conclusions of Kubová et al. (2013) that environmental variables are a less significant predictor of leech assemblage composition than biotic variables (i.e. prey availability).

To conclude, the analyzed environmental factors have a slight influence on the distribution and diversity of leeches in spring ecosystems. It is likely that the combination of a specific set of biotic and abiotic factors in microhabitats determines the distribution of this interesting group of aquatic macroinvertebrates.

\section{Supplementary Material}

Appendix 1. Name of the karst springs with GPS-position and description of the types of springs.

Appendix 2. a: Leeches taxonomy list; b: Qualitative composition of leeches.

Appendix 3. Classes of frequency based on percentage of cover for habitat in five types of karst springs of Montenegro.

The Supplementary Material is available at https://www.kmaejournal.org/10.1051/kmae/2019019/olm.

Acknowledgments. The study was supported by the Serbian Ministry of Education, Science and Technological Development-Grant No. 37009 and 176018 . We would like to express our appreciation for very useful comments and suggestions given by the reviewers. Also we would like to thank to Dr. Goran Poznanović from the Institute for Biological Research "Siniša Stanković", University of Belgrade, for his help in language editing the manuscript.

\section{References}

Adamiak-Brud Z, Jabłońska-Barna I, Bielecki A, Kobak J. 2018. Factors shaping leech (Clitellata, Hirudinida) assemblages on artificial and natural substrata in urban water bodies. Limnologica 69: 125-134.

Agapow L, Piekarska A. 2000. Benthic fauna of rivers Santoczna and Pelcz (West Pomeranian Lake District, Poland), with a particular reference to leeches (Hirudinea) and molluscs (Mollusca). Pol Arch Hydrobiol 47(2): 281-303.

Anderson MJ. 2001. A new method for non-parametric multivariate analysis of variance. Austral Ecol 26(1): 32-46.

Anderson MJ. 2005. PERMANOVA: A FORTRAN computer program for permutational multivariate analysis of variance. New Zealand: Department of Statistics, University of Auckland, $24 \mathrm{p}$.

AQEM. 2002. Manual for the application of the AQEM system. A comprehensive method to assess European streams using benthic macroinvertebrates, developed for the purpose of the Water Framework Directive.

Augener H. 1937. Hirudineen aus jugoslavischen Seen. Festschrift zum 60. Geburtstag vom Embrik Strand 2: 403-413.

Barović G, Spalević V, Pešić V, Vujačić D. 2018. The physical and geographical characteristics of the Lake Skadar Basin. In Pešić V, Karaman G, Kostianoy A, eds. The Skadar/Shkodra Lake Environment. The Handbook of Environmental Chemistry, Vol. 80. Cham: Springer, pp. 11-23.

Baselga A. 2010. Partitioning the turnover and nestedness components of beta diversity. Glob Ecol Biogeogr 19(1): 134-143.

Beracko P, Košel V. 2011. Life cycle and feeding habits of Dina punctata Johansson, 1927 (Erpobdellidae, Hirudinea) in a small Carpathian stream. Int Rev Hydrobiol 96(1): 39-47. 
Blanchard R. 1905. Hirudineen aus Montenegro. Sitzs-ber Königl Böhm Ges Wiss, Prag, pp. 1-3.

Borda E, Siddall ME. 2004. Review of the evolution of life history strategies and phylogeny of the Hirudinida (Annelida: Oligochaeta). Lauterbornia 52: 5-25.

Cichocka J, Jabłońska-Barna I, Bielecki A, Buczyńska E, Buczyński P, Stryjecki R, Pikuła D. 2015. Leeches (Clitellata: Hirudinida) of an upland stream: Taxonomic composition in relation to habitat conditions. Oceanol Hydrobiol Stud 44(2): 245-253.

Di Sabatino A, Cicolani B, Gerecke R. 2003. Biodiversity and distribution of water mites (Acari, Hydrachnidia) in spring habitats. Freshw Biol 48(12): 2163-2173.

Elliott JM, Mann KH. 1979. A key to the British freshwater leeches: With notes on their life cycles and ecology. Ambleside: Freshwater Biological Association, Scientific Publication No.40, 72 p.

Fisher RA. 1936. The use of multiple measurements in taxonomic problems. Ann Hum Genet 7(2): 179-188.

Friese K, Frömmichen R, Witter B, Müller H. 2004. Determination of trace metals in the freshwater leech Erpobdella octoculata of the Elbe River-Evaluation of the analytical protocol. Acta Hydrochim Hydrobiol 31(4-5): 346-355.

Greenacre MJ. 2010. Biplots in practice. Barcelona: Fundación BBVA, $237 \mathrm{p}$.

Grosser C, Pešić V. 2005. First record of Batracobdelloides moogi (Hirudinea: Glossiphoniidae) in the Balkans. Nat Montenegr 4: 29-32.

Grosser C, Moritz G, Pešić V. 2007. Dina minuoculata sp. nov. (Hirudinea: Erpobdellidae)-eine neue Egelart aus Montenegro. Lauterbornia 59: 7-18.

Grosser C, Pešić V, Gligorović B. 2014a. A checklist of the leeches (Annelida: Hirudinea) of Montenegro. Ecol Montenegrina 2(1): $20-28$.

Grosser C, Pešić V, Dmitrović D. 2014b. Dina sketi n. sp., a new erpobdellid leech (Hirudinida: Erpobdellidae) from Bosnia and Herzegovina. Zootaxa 3793(3): 393-397.

Grosser C, Pešić V, Berlajolli V, Gligorović B. 2016. Glossiphonia balcanica n. sp. and Dina prokletijaca n. sp. (Hirudinida: Glossiphoniidae, Erpobdellidae) - Two new leeches from Montenegro and Kosovo. Ecol Montenegrina 8: 17-26.

Hastie T, Tibshirani R, Friedman J. 2009. The elements of statistical learning, 2nd edition. New York: Springer, $745 \mathrm{p}$.

Karadžić B. 2013. FLORA: A software package for statistical analysis of ecological data. Water Res Manag 3(1): 45-54.

Kazanci N, Ekingen P, Dügel M, Türkmen G. 2015. Hirudinea (Annelida) species and their ecological preferences in some running waters and lakes. Int J Environ Sci Technol 12(3): 1087-1096.

Koperski P. 2006. Relative importance of factors determining diversity and composition of freshwater leech assemblages (Hirudinea; Clitellata): A metanalysis. Arch Hydrobiol 166(3): 325-341.

Koperski P. 2010. Urban environments as habitats for rare aquatic species: The case of leeches (Euhirudinea, Clitellata) in Warsaw freshwaters. Limnologica 40(3): 233-240.

Koperski P. 2017. Taxonomic, phylogenetic and functional diversity of leeches (Hirudinea) and their suitability in biological assessment of environmental quality. Knowl Manag Aquat Ecosyst 418(49): $1-14$.

Kubová N, Schenková J. 2014. Tolerance, optimum ranges and ecological requirements of free-living leech species (Clitellata: Hirudinida). Arch Hydrobiol 185(2): 167-180.

Kubová N, Schenková J, Horsák M. 2013. Environmental determinants of leech assemblage patterns in lotic and lenitic habitats. Limnologica 43(6): 516-524.
Legendre P. 2014. Interpreting the replacement and richness difference components of beta diversity. Glob Ecol Biogeogr 23 (11): 1324-1334.

Legendre P, Anderson MJ. 1999. Distance-based redundancy analysis: Testing multispecies responses in multifactorial ecological experiments. Ecol Monogr 69(1): 1-24.

Lloyd M, Ghelardi RJ. 1964. A table for calculating the equitability component of species diversity. J Anim Ecol 33(2): 217-225.

Lunghi E, Ficetola GF, Mulargia M, Cogoni R, Veith M, Corti C, Manenti R. 2018. Batracobdella leeches, environmental features and Hydromantes salamanders. Int J Parasitol 7(1): 48-53.

MacArthur RH. 1984. Geographical ecology: Patterns in the distribution of species. Princeton University Press, $288 \mathrm{p}$.

MacQueen J. 1967. Some methods for classification and analysis of multivariate observations, in Proceedings of the Fifth Berkeley Symposium on Mathematical Statistics and Probability, Vol. (4), University of California Press, Los Angeles, pp. 281-297.

Miller AJ. 1984. Selection of subsets of regression variables. $J R$ Stat Soc Ser A Stat Soc 147(3): 389-425.

Moog O. 2002. Fauna Aquatica Austriaca. A comprehensive species inventory of Austrian aquatic organisms with ecological notes. Vienna: Federal Ministry of Agriculture Forestry, Environment and Water Management.

Nesemann H, Neubert E. 1999. Süßwasserfauna von Mitteleuropa, Bd. 6, Annelida, 2, Clitellata: Branchiobdellida, Acanthobdellea, Hirudinea. Heidelberg, Berlin: Spektrum Akademischer Verlag, $178 \mathrm{p}$.

Pešić V, Karaman GS, Kostianoy AG, Vukašinović-Pešić V. 2018. Conclusions: Recent advances and the future prospects of the lake Skadar/Skhodra environment. In Pešić V, Karaman G, Kostianoy AG, eds. The Skadar/Shkodra Lake Environment. The Handbook of Environmental Chemistry, Vol. 80. Cham: Springer, pp. 481-500.

Pianka ER. 1974. Evolutionary ecology. New York and Austin, TX: Harper and Row and University of Texas, $356 \mathrm{p}$.

Pielou EC. 1969. An introduction to mathematical ecology. New York: Wiley-Interscience, $286 \mathrm{p}$.

Pielou EC. 1974. Population and community ecology. New York: Gordon and Breach Science Publication, $424 \mathrm{p}$.

Podani J, Ricotta C, Schmera D. 2013. A general framework for analyzing beta diversity, nestedness and related community-level phenomena based on abundance data. Ecol Complex 15: 52-61.

Radulović M, Radulović M, Stevanović Z, Sekulić G, Radulovi V, Burić M, Novaković D, Vako E, Blagojević M, Dević N, Radojević D. 2015. Hydrogeology of the Skadar Lake Basin (Southeast Dinarides) with an assessment of considerable subterranean inflow. Environ Earth Sci 74(1): 71-82.

Rémy P. 1937. Sangsues de Yougoslavie. Bull Soc Zool Fr 62: 140-148. Šapkarev J. 1975. Contribution to the knowledge the earthworms (Lumbricidae) and leeches (Hirudinea) of Kosovo, Yugoslavia, Vol.27. Annuaire de la Faculté des Sciences de l'Université de Skopje, Skopje, pp. 39-54.

Sket B. 1968. K Poznavanju Favne Pijavk (Hirudinea) v Jugoslaviji, Zur Kenntnis der Egelfauna (Hirudinea) Jugoslawiens. Diss 9(4): 127-197. Ljubljana: Academia Scientiarum et Artium Slovenica Classis IV: Historia Naturalis et Medicina.

Springer E, Stevens L. 2009. Spheres of discharge of springs. Hydrogeol J 17(1). 83-93.

Spyra A, Krodkiewska M. 2013. The significance of woodland ponds in the conservation of rare species: A case study of Placobdella costata (F. Müller) (Hirudinida: Glossiphoniidae). Pol J Ecol 61 (3): 613-619.

Stendera S, Adrian R, Bonada N, Cañedo-Argüelles M, Hugueny B, Januschke K, Hering D. 2012. Drivers and stressors of freshwater 
N. Marinković et al.: Knowl. Manag. Aquat. Ecosyst. 2019, 420, 26

biodiversity patterns across different ecosystems and scales: A review. Hydrobiologia 696(1): 1-28.

Ter Braak CJ. 1986. Canonical correspondence analysis: A new eigenvector technique for multivariate direct gradient analysis. Ecology 67(5): 1167-1179.

Utevsky S, Utevsky A, Pešić V. 2013. First record of Glossiphonia nebulosa (Hirudinida: Glossiphoniidae) from the Skadar Lake in Montenegro. Lauterbornia 76: 123-125.

Utevsky SY, Son MO, Dyadichko VG, Kaygorodova JA. 2012. New information on the geographical distribution of Erpobdella vilnensis (Liskiewicz, 1915) (Hirudinida, Erpobdellidae) in Ukraine. Lauterbornia 75: 75-78. von Fumetti S, Nagel P, Scheifhacken N, Baltes B. 2006. Factors governing macrozoobenthic assemblages in perennial springs in north-western Switzerland. Hydrobiologia 568(1): 467-475.

Whittaker RH. 1972. Evolution and measurement of species diversity. Taxon 21(2-3): 213-251.

Živić I, Radosavljević T, Stojanović K, Petrović A. 2015. The first molecular characterization of the genus Hirudo on the territory of Serbia: Estimation of endangerment. Aquat Ecol 49(1): $81-90$.

Živić I, Cvetković A, Božanić M, Radojević A, Stojanović K. 2017. Checklist of Freshwater Leeches (Hirudinea) in Serbia. Water Res Manag 7(3): 35-41.

Cite this article as: Marinković N, Karadžić B, Pešić V, Gligorović B, Grosser C, Paunović M, Nikolić V, Raković M. 2019. Faunistic patterns and diversity components of leech assemblages in karst springs of Montenegro. Knowl. Manag. Aquat. Ecosyst., $420,26$. 